\title{
Madrasah al-Ula for Children: An Effective Learning Management in the Family during Covid-19 Pandemic
}

\author{
Mahyudin Ritonga, Muhammadiyah University of West Sumatera, Indonesia, \\ mahyudinritonga@gmail.com \\ Fitria Sartika, Muhammadiyah University of West Sumatera, Indonesia, fitriasartika22@gmail.com \\ *Martin Kustati, Universitas Islam Negeri Imam Bonjol Padang, Indonesia, martinkustati@uinib.ac.id \\ *Corresponding Author
}

\begin{abstract}
The problem was raised from the importance of families' involvement in educating their children during Covid-19 pandemic in order to get the maximum result of the learning activities. During the pandemic, children interact intensely with their parents since their school materials are transferred from school and must be done at home. This study aims to find out how parents plan, implement, evaluate, and encounter the problems in assisting their children learning Islamic subject during Covid-19 pandemic. A qualitative approach with case study design was implemented and the data were taken from observation and interview. The result of the study showed that children's education can be implemented at home in a simple way by integrating Madrasa al-Ula. Without having clear planning, appropriate materials, methods and techniques, assessment, tools of learning, the process would make the children have difficulties in learning. Thus, both teachers and parents have to collaborate in appropriate way to facilitate learning process. Teachers must employ teaching methods and techniques based on parents' abilities and provide the alternative form of examination, unlike the structured test in school.
\end{abstract}

Keywords: Madrasah al-Ula, Learning Management, Covid-19 Pandemic, Implementation Received: 20.11.2020 Accepted: 12.12.2020 $\quad$ Published: 08.01.2021

\section{INTRODUCTION}

Covid-19 pandemic have changed some natural order of human life. First, shopping centers that are usually crowded with buyers must be prepared with the absence of buyers (Baldwin, 2020; Barbieri et al., 2020; Bell et al., 2020; del Rio-Chanona et al., 2020; Ramelli \& Wagner, 2020). Second, it influenced the activities in the places of worship churches, mosques, temples which were usually crowded with people in performing worship in this very situation must be closed (Hagenbuch, 2020). Next, employees who usually carry out their duties in the office must be able to complete their duties from home, with low income, and difficulty to find the job (Monitor, 2020). Then, students who normally enjoy the learning process at school or campus must switch to the daring system (Murphy, 2020); (Viner et al., 2020). In fact, many education observers specifically published the study guides during the Covid-19 pandemic period that can be used as a reference for learning from home.

Related to learning from home, long before covid-19 and before the publication of various study guides from home, Islam already had a concept of family education called "al-Usrah Madrasah al-Ula" or the family as the first and foremost educational institution. This concept is then abandoned by many families because of various busy activities of parents (Suciati, 2016). It is also because of the availability of educational institutions that are ready to provide the best service and guidance to develop children's potential that left parents only to support their children by funding and providing children's learning needs to complete their parental responsibilities. However, in the recent condition, with the outbreak of coronavirus disease 2019 or better known as the Covid-19 pandemic, all forms of children's educational activities at school must be conducted at home (Lipsitch et al., 2020; Viner et al., 2020). In other words, all teaching and learning activities in educational institutions are shifted as home schooling or learning from home (Murphy, 2020). Also, for some parents, they need to shift their working condition at home or commonly called as work from home. This situation leads to the higher intensity for parents and children to interact as a family and this is where the implementation of madarasah al-ula needs to be increased because in this situation parents will have a dual role, as the parents and the teachers for their children.

As a "madrasa al-ula" or first educational institution, the family has a very large role in the growth and development of the children (Idris, 2017). Education obtained in the family also becomes a barometer of children attitude and behavior for their adulthood. In Islam, family education is in the highest position called madrasatul ula or tarbiyatul ula. In the Quran surrah At-Tahrim (66:6), it is 
emphasized to preserve themselves and their families from all the torments of hellfire, and Allah SWT also gives an illustration that the fuel of the hellfire are humans and stones, which is guarded by angels who would terrify the sinful humans, and the angels are the creatures who fully obey Allah SWT. The verse shows the mandate to educate children in the family. The process needs to be considered and conducted properly according to Islamic teachings.

Performing the duty as an educator is not an easy job for some parents. From the cases found during the covid-19 pandemic and the implementation of Large-Scale Social Distancing (Pembatasan Sosial Berskala Besar- PSBB) in West Sumatra many parents complained about how to educate their children at home, especially related to the assignment given by teachers at school. This condition has affected many children in completing their learning from home assignment from school. The inability to teach is normal since everyone has different traits. However, in a pandemic condition every parent must be able to be the substitute teacher for their children and actualizes the concept of "al-madrasa al-ula."

Therefore, this paper focuses on the implementation of education in the family during the Covid19 pandemic, and the problems faced by parents as educators in implementing madrasa al-ula as the main education for children during the Covid-19 pandemic. The aims of this paper are to determine how far families are able to assist children learning activities during the pandemic and to figure out problems faced by parents in the process. Thus, educational activities during the Covid-19 epidemic could be an evaluation material for parents and education observers to enhance the role of families in supporting the continuity of children's education, as well as providing reinforcement of knowledge to the wider community about the importance of education in the family.

\section{METHODS}

This study uses a qualitative approach with case study, which is a study that wants to examine in depth the phenomenon in the community about the education conducted in the family during the Covid-19 pandemic. The data source of this study was 30 parents of students affected by covid- 19 pandemic, the research data collection technique was conducted in structured interview by phone which was strengthened by the distribution of online open-ended questionnaire. Both of these techniques are used because researchers and informants are unlikely to meet directly because they are limited by the rules of Large-Scale Social Distancing.

The results of the telephone interview were then recorded to store information obtained from the informants, while the questionnaire entries were asked to the informants to take pictures and send them to researchers via WhatsApp. In analyzing the research data, researchers conducted data reduction, data display, classification and conclusion drawing. To ensure the validity of the data the researcher verifies the informant and compares it with information obtained from other informants and information obtained from the questionnaire.

\section{RESULTS}

In implementing Madrasa al-ula in the family, here are the results of interviews conducted by telephone and open-ended questionnaire described in table 1 below:

Table 1. Learning at home through Madrasah-al ula

\begin{tabular}{|c|c|c|}
\hline No. & Aspect & Parents' opinions \\
\hline 1 & $\begin{array}{l}\text { Planning for learning done by } \\
\text { parents }\end{array}$ & $\begin{array}{l}\text { 1. Planning is only in the form of learning facilities, such as } \\
\text { special learning spaces so that children are comfortable } \\
\text { learning at home. } \\
\text { 2. Making learning schedule and taking some notes for the } \\
\text { subjects that the children must learn. } \\
\text { 3. Preparing tools that support the implementation of } \\
\text { children's learning, e.g. android phone and data plan. } \\
\text { 4. Do not have a plan or preparation for children's learning } \\
\text { at home, because they have to work to meet their daily } \\
\text { needs. }\end{array}$ \\
\hline 2 & $\begin{array}{l}\text { Implementation of learning } \\
\text { conducted by parents }\end{array}$ & $\begin{array}{l}\text { 1. Children's learning schedule is adjusted to the study } \\
\text { schedule at school, the child must be online. } \\
\text { 2. Children's learning materials in accordance with the } \\
\text { instructions of teachers at school, assignments are } \\
\text { collected at the end of the learning hours to teachers }\end{array}$ \\
\hline
\end{tabular}




\begin{tabular}{|c|c|c|}
\hline No. & Aspect & Parents' opinions \\
\hline & & $\begin{array}{l}\text { online. } \\
\text { 3. Learning schedules may be adjusted by parents, material } \\
\text { from school, but the report must be sent to the teacher } \\
\text { on the very day. } \\
\text { 4. Motivation given by parents to children in learning in the } \\
\text { form of gifts or what children like. } \\
\text { 5. Assignments given by the teacher to children before the } \\
\text { holidays are collected after returning to school. } \\
\text { 6. Do not use one of the methods commonly used by school } \\
\text { teachers, each method, the wisdom method used to make } \\
\text { children calm, memorization method is used to } \\
\text { memorize verses by children } \\
\text { 7. The media used are android, and blackboard. }\end{array}$ \\
\hline 3 & $\begin{array}{l}\text { Evaluation of learning conducted } \\
\text { by parents }\end{array}$ & $\begin{array}{l}\text { 1. Evaluation through children's notebooks or assignments. } \\
\text { 2. Observe the attitudes and behavior of children, pay } \\
\text { attention to the implementation of the children's } \\
\text { worship. } \\
\text { 3. Do not use written tests or exams like in school. }\end{array}$ \\
\hline
\end{tabular}

The results in table 1 above are data that has been classified according to the focus of the study obtained based on a telephone interview with parents of students as well as an analysis of the openended questionnaire answer distributed to all parents of students affected by covid-19 pendemic.

In line with the position of the family as the first school, the condition of Covid-19 pandemic increasingly made parents aware of their duties as educators, so that from the results of interviews by phon they stated all abilities devoted to educating children at home, because the current situation there is no reason for people parents not to educate their children.

\section{Planning done by parents in Educating Children during Covid-19 Pandemic}

To implement an education requires planning. According to Hady planning is the process of determining the steps that will be taken to achieve the learning objectives (Bin-Hady \& Abdulsafi, 2018). As befits the sustainability of an education, careful planning is needed before learning is carried out (Hodgson \& Walford, 2007), so that the material will be delivered by educators to students in order to achieve the expected goals. Likewise with the education of children in family institutions, there must be plans made by parents as educators to educate their children at home.

During the pandemic, parents are given the authority to teach their children what they should be learned with teachers at school. It forces parents to design the learning plans according to their respective abilities. Based on the results of telephone interviews conducted by researchers of parents, there are parents who prepare a special room for children's learning during the pandemic, some make a simple device in the form of a schedule of children's learning hours, subjects to be taught, then prepare learning tools that needed, this is done so that children are comfortable learning at home.

For lower class children in some primary education institutions, children are only given assignments by the teacher to do at home during the pandemic holiday period and then handed over to the teacher when returning to school later. But, in general the school or teacher applies online learning for all levels, both lower and high class. In junior and senior high school level, online learning is conducted through the parents' mobile phone either in sending assignments or photo documentation as the proof for their learning at home activities.

This online learning is done through the WhatsApp application, this makes parents have to increase expenses, in the form of additional android phone and additional data plan. Based on the questionnaire, it appears that some parents also work from home, e.g. teachers, employees, etc. that they have to get the new android phone to support their children's learning. Also, for parents who do not yet have an android phone, this situation forces them to buy an android phone for the implementation of their children's education because android phone is needed by their children as a tool for learning. This Android phone is required for submission of excercises, assignment, and documenting other learning activities at home in the pandemic.

Various forms of preparation held by parents, of course, can only be done for those who have the ability to do and also for ones who have plenty of time to monitor the learning continuity of their children. However, many parents have no preparation or planning at all because parents have to work to make a living for their family. Preparing for survival needs is certainly preferable to preparing children's school 
education at home so that there are also few parents who only submit learning activities to their children. It is not because they do not want to help and assist the children but there are also basic needs that they must meet for the family.

\section{Implementation of Education by Parents during Covid-19 Pandemic}

The effectivenees or not a plan can be seen in its implementation. Teaching and learning activities is the principal of an educational activity. All the planning and preparation that has been prepared will be implemented to achieve the learning objectives (Hackathorn et al., 2011). In planning there should be a learning schedule, the material that will be delivered, the methods that will be used in teaching, and teaching media to support teaching and learning activities. So, in implementing learning activities, children will not experience any difficulties or significant obstacles, and focus on dealing with learning material.

The process of teaching and learning activities undertaken by parents with children at home during the pandemic are carried out in various forms. From the results of the interview and also the contents of the questionnaire, it appears that teaching and learning activities of children at home depends on the policy of the subject teacher or school teacher of each child. Also, in arranging children's learning schedules at home, there are some schools that require parents to teach children according to the schedule of the subject at school, so that during these learning hours parents must monitor and assist their children's learning activities. For elementary school children must be accompanied directly. Children's learning activities are documented in the form of photos or videos, after the assignments are completed, the parents immediately send proof that the child is learning, and also the proof of the assignment has been done to the subject teacher through WhatsApp service. As acknowledged by some informants said that some teachers handed over their study schedules to parents, so that children's learning hours were adjusted to their parents' free time. With a note on that day parents must send proof that the task given has been completed by the child.

In teaching and learning activities in schools, before explaining the material, usually the teacher will motivate students, so that they are comfortable and interested in following the learning material to be delivered. Providing this motivation becomes important to take over the children's focus on learning. However, what happens at home now is certainly different. From the questionnaire answers, it appears that some parents can only motivate children to learn with promises, such as; if the outbreak is over children will be invited to walk to visit a place they like; if their children want to learn they will be taken out of the house for a while in the afternoon; given more allowance; buy favorite foods or toys; and some are motivating their children with praise and compliment.

Various ways are sought by parents so that their children do not get bored and want to study at home. The material or subject matter must also be communicated with the teacher at the school. In the learning process there are certainly materials or materials that will be taught by educators to students, as well as children's learning at home during this pandemic. There are learning materials that are basic, and there are complementary or supporting materials in the learning process (Basak et al., 2018). Even though the parents who act as teachers are parents, the subject matter of the children is still adjusted to the teaching material delivered by the teacher at school. This material is delivered by teachers to parents through WhatsApp Group and the parents must prepare supporting material in the form of tools that will be used by children in learning e.g. android phone. For junior high and high school level children, the teacher sends the material to their respective class groups and then the children do the assignment according to the teacher's explanation.

As befits the process of teaching and learning activities, a method is needed to convey learning. Among the learning methods commonly used by teachers in schools are; Methods of lecture, discussion, demonstration, assignment, drill, wisdom, rote learning, and others.

Of the various learning methods available, parents can only apply the assignment and rote learning methods for completing tasks from school, in other words only instruct and accompany the child to do the assignments given by the teacher, then listen to the memorization of the Qur'an which has been memorized by the children, The rote is also deposited to teachers at school via Android phone.

The questionnaire shows that in general parents do not use one particular method from the various methods available, except parents who work as teachers, of course this can be applied at home when teaching their children. However, some parents say that they have invited their children to take wisdom from a pandemic outbreak. This is done so that children feel comfortable studying at home with their parents. Means, the wisdom method is also applied by parents, although it is not maximal to deliver school subject matter. In Islam, the wisdom method is one of the methods used to convey learning by teachers to students, or by parents to their children. 
To support the learning process or teaching and learning activities required teaching media. Media is a tool used by teachers in the classroom in the teaching process, which can help teachers to deliver learning material so that the material is more easily understood by students (Aleksandrov \& Levitskaya, 2018). All educational facilities are used by teachers in order to convey science material and other values to students including the media (Suh, 2011). In general, learning media include people, materials, equipment, or activities that create situations and conditions that enable students to learn in order to gain knowledge, skills, and attitudes.

So, learning media means all the tools used by the teacher during learning, in order to convey knowledge, facts, ideas, and meanings to students. When children learn with their parents at home, parents generally only rely on the media in the form of android as a supporting medium to help their children learn. Some of them use the blackboard to explain the subject matter to their children.

Here, the implementation of children's learning activities at home during the pandemic have made parents to try their best to support the continuity of formal education of their children. Even though it does not go smoothly according to what is in school, but it can still be done with a variety of current technologies that can be used to support teaching and learning activities.

\section{Form of Learning Evaluation conducted by Parents during the Covid-19 Pandemic}

The success of a learning process can be seen from the evaluation conducted. In Islamic education, evaluation is one component of the education system that must be planned and systematic to measure the success of the learning process that has been carried out (Hanberger, 2011).

Based on telephone interviews conducted with parents, parents generally evaluate children's learning during this pandemic through children's notebooks, and adjust them to the assignments given by the teacher. Some parents have listened back to their children's memorization or muraja'ah. Another form of evaluation conducted by parents viewed from the answers to the questionnaire is an observation of the behavior and attitudes of children during this pandemic, so parents can see firsthand the extent of learning that affects the morals of their children.

From the telephone interview conducted by the researchers, parents do not provided test material in the form of questions or specific questions related to the material that the child had learned during this pandemic at home. Limited time and ability or limited knowledge of parents in the field of education, is one of the reasons they cannot carry out evaluations as befits an evaluation of education in schools. So it appears that learning at home can only be evaluated in a few specific things, while evaluations to assess a child's cognitive abilities cannot be carried out to the maximum.

Based on the data above it is known that parents do not conduct evaluations as is the evaluation in schools, because parents also do not need to give grades to their children due to the right to set grades as will be stated in the education report book later it will remain teachers in the school .

As for the problems faced by parents in implementing Madrasa al-ula during the Covid-19 pandemic, according to the results of interviews and the answers to questionnaires distributed are in table 2 below:

Table 2. Problems faced by parents in the implementation of Madarasah al-ula during Covid-19 pandemic

\begin{tabular}{|c|c|c|}
\hline No. & Aspect & Obstacles encountered \\
\hline 1 & Learning planning problems & $\begin{array}{l}\text { 1. Do not understand the planning that must be designed. } \\
\text { 2. Android phone is only owned by parents, the urgency } \\
\text { to buy the new one. } \\
\text { 3. Does not have an android phone, the urgency to buy } \\
\text { the new one. } \\
\text { 4. Cannot afford to but data plan. }\end{array}$ \\
\hline 2 & $\begin{array}{l}\text { Problems in the implementation of } \\
\text { learning }\end{array}$ & $\begin{array}{l}\text { 1. Parents are busy with the household activities, while } \\
\text { children cannot learn on their own, and will not be able } \\
\text { to learn without the assistant. } \\
\text { 2. Parents do not have educational qualifications that are } \\
\text { appropriate to the learning materials. } \\
\text { 3. The curriculum used by the school material is difficult } \\
\text { for parents. } \\
\text { 4. Children are less responsive to what is explained by } \\
\text { parents, because it is not the same as the way the } \\
\text { teacher explains at school. } \\
\text { 5. Children are lazy because they are used to be spoiled }\end{array}$ \\
\hline
\end{tabular}




\begin{tabular}{|l|l|l|}
\hline No. & Aspect & Obstacles encountered \\
\hline & & $\begin{array}{l}\text { by their parents. } \\
\text { 6. Children are bored and fed up because there are too } \\
\text { many exercises given by the teachers that they do not } \\
\text { have enough playtimes. }\end{array}$ \\
\hline 3 & Problems during the evaluation & $\begin{array}{l}\text { 7earning by using Android phones will make children } \\
\text { ask for extra time to play the game after, so it is } \\
\text { difficult to control it. }\end{array}$ \\
\hline
\end{tabular}

Some of the problems described above are taken from the information that is evenly expressed by all research informants, because informants who have the good ability in teaching are also hindered by other aspects such as the availability of the android phone or data plan, so that many parents must borrow the android phone to their neighbor in order to find out about their children's assignments that are communicated through WA groups and resend the results of their work through the neighbor's phones.

Intensive togetherness between parents and children during the pandemic raises various problems in conducting education of children at home. This can be seen from the answers to the questionnaire and the results of the telephone interview conducted by the researcher towards parents, various problems and complaints raised by parents through interviews and answers to the questionnaire. Obligation to make a living and take care of family members is one problem that makes parents overwhelmed carrying out children's learning activities at home.

As a mother who has to take care of several children and a father who has to work to make a living, making the process of children's education during this pandemic does not run smoothly. Some informants said that they had tried to divide their time to accompany other children to study and work at home. However, the reality is also not in accordance with the wishes, when parents have taken the time, the child does not want to learn. When his parents are busy working with their activities the child asks to study. This happens to children in grades 1-3 elementary school, so some of the tasks given by the teacher are finished late.

In the learning process, there are materials that must be understood and mastered by children. Based on telephone interviews with parents, researchers obtained information that learning materials that children must learn at home come from subject teachers at school. So many parents do not understand the material. Moreover, in general these informants do not have educational qualifications that are appropriate for their children's learning. This can also be seen from the answers to the questionnaire, in general these parents are high school graduates, so that when children are faced with religious studies, parents will be overwhelmed, some of them will contact the religious teachers they know to help their children learn.

Likewise with parents who graduated form Islamic high school (Madrasah Aaliyah), in general lessons they are less mastered, especially the level of difficulty of children's subject matter today is far higher than what they have learned when school previously. The 2013 curriculum implemented by the school is one of the things parents complain about. Because parents are not able to help, so children must learn on their own, or find out about these matters through Android phone apps.

Another problem that arises when children learn with parents is the tendency of spoiled children's attitudes toward parents. From the results of telephone interviews with parents, many children are difficult to control learning and tend to be spoiled when they are with parents at home. It is different from the way the child learns in school, which can be obedient and diligent when learning takes place. This makes it difficult for some parents to deal with it, and the learning process cannot be carried out optimally as expected.

Other problems also arise from several informants, namely the task of children who are given too much by the teacher to make children have no time to play, school-age children still need hours of playing a few hours each day. It can't be forced to deal with too much material. So that children get bored studying at home, because they have to deal with the task that never finished.

The answer to the questionnaire also shows that some children compare their teachers with their parents. When parents try to understand the learning material, thy try to explain it, the child compares 
the way their teachers at school teach with the way their parents teach at home. So that children are less responsive to what is conveyed by their parents.

When children learn to use Android, from several informants complained about the difficulty of controlling the time of use of the Android on children. Children will ask for more time to play games than study. Theree are many other problems that arise during this pandemic in the implementation of children's education at the al-usrah institution. However, for junior and senior high school students, the problems faced by parents are not so obvious, they only need to increase their spending to buy data plan or to buy a new android phone that is adequate for the learning activities.

\section{DISCUSSION AND CONCLUSIONS}

Implementation of education is an activity that involves all components of education to achieve overall educational goals. Family as Madarasah al-ula is a concept for informal and natural educational institutions commonly referred to as family. The family is a place to live and a natural environment that is the first and foremost institution for children in their lives, which aims to nurture and educate children, without the case of covid-19 also the child's education will not succeed if there is no active role of the family (Maunah, 2019) because in the family environment every child will get education or influence from their parents.

As Madrasa al-ula, in the family, children will obtain social, morals, and ruhiyyah values according to religious teaching (Tiliouine, 2014) (Roostin, 2018). Parents as excellent educators have a very important role in the lives of every child, especially Mother. With education, children will be able to take part in society; can overcome various problems encountered in life. Education starts from the family (M. Barnett et al., 2019) before and after the child is born into the world and continues until the end of life in order to educate the generation to become a formidable generation to build a better society.

The family education institution or al-usrah is the smallest unit in society consisting of a group of people who have certain patterns in educating their children. Educational activities in the family without having a binding organization, without a standard program, without clear planning, do not have special materials and methods, and also without a scheduled or structured evaluation. The family becomes the first place for children to get an education to shape the nature and personality in life. Some of the thoughts above can be concluded that the family as a primary educational institution, parents, relatives, family, and everyone in the family environment become educators for children who are still learning.

Family and education are two things that can not be separated, because it has become the nature and must be recognized that the family is one of the three Education Centers that organizes education including family, school, and community. However, among these three institutions the family environment has the strongest influence on children's growth and development (Desforges \& Abouchaar, 2003). The main points of Islamic education in the family are able to make children understand their position and role in life, especially as a servant of God, then the child will know and understand the norms of other Islamic teachings well (Tiliouine, 2014).

In line with the position of the family as the first school, the condition of Covid-19 pandemic increasingly made parents aware of their duties as educators, so that from the results of interviews by phon they stated all abilities devoted to educating children at home, because the current situation there is no reason for people parents not to educate their children.

It can be concluded that the implementation of al-madarasah al-ula during the Covid-19 pandemic could generally be conducted. Simple planning can be designed by parents to support the continuity of the child's learning process at home, but not in the form of structured planning as done by teachers at school. Children study schedules at home there are learning according to school hours, and there are adjusted to the parents' spare time at home. In the process of teaching and learning activities, the subject matter is adjusted to what is given by the teacher from the school, the methods used are adjusted to the ability of parents, while the evaluation of learning done by parents is only through the child's task book and observing the attitudes and behavior of children, without going through structured tests as in school.

The implementation of learning activities at home during the pandemic can not be separated from various forms of problems that must be faced by parents. Parents routines at home are dense, children's learning materials now tend to be difficult so that it cannot be understood by parents, parents' education factors also cause the lack of smooth teaching and learning activities of children at home, children who tend to be spoiled, or who are more idolizing teachers in learning makes children less responsive and uncomfortable learning with parents. Some children get too many tasks from the teacher, so that children feel bored, the difficulty of controlling the use of android on children, and various other problems that can not be avoided. Here, the implementation of children's education at home during the 
Covid-19 pandemic can be said to have not been carried out optimally to achieve the expected educational goals.

\section{REFERENCES}

Aleksandrov, E., \& Levitskaya, A. (2018). Technology of Integrated Media Education. Media Education (Mediaobrazovanie), 58(4), 3-10. https://doi.org/10.13187/me.2018.4.3.

Baldwin, R. (2020). Keeping the lights on: Economic medicine for a medical shock. Macroeconomics, 20, 20.

Barbieri, T., Basso, G., \& Scicchitano, S. (2020). COVID-19 epidemic: Italian workers exposed to risk and the lockdown. CEPR Vox. Eu.

Basak, S. K., Wotto, M., \& Belanger, P. (2018). E-Learning, M-Learning and D-Learning: Conceptual Definition and Comparative Analysis. E-Learning and Digital Media, 15(4), 191-216. https://doi.org/10.1177/2042753018785180.

Bell, B., Bloom, N., Blundell, J., Pistaferri, L., Vandenbroucke, F., Andor, L., Beetsma, R., Burgoon, B., Fischer, G., \& Kuhn, T. (2020). Rescuing the labour market in times of COVID-19: Don't forget new hires!.

Bin-Hady, W. R. A., \& Abdulsafi, A. S. T. (2018). How Can I Prepare an Ideal Lesson-Plan? International Journal of English and Education, 7(4), 275-289. https://doi.org/10.2139/ssrn.3434031.

del Rio-Chanona, R. M., Mealy, P., Pichler, A., Lafond, F., \& Farmer, D. (2020). Supply and demand shocks in the COVID-19 pandemic: An industry and occupation perspective. ArXiv Preprint ArXiv:2004.06759.

Desforges, C., \& Abouchaar, A. (2003). The Impact of Parental Involvement, Parental Support and Family Education on Pupil Achievements and Adjustment: A Literature Review with. In Education (Vol. 30, Issue 8). https://doi.org/10.1016/j.ctrv.2004.06.001.

Hackathorn, J., Solomon, E. D., Blankmeyer, K. L., Tennial, R. E., \& Gareczynski, A. M. (2011). Learning by Doing: An Empirical Study of Active Teaching Techniques. JET-The Journal of Effective Teaching, 11(2), 40-54.

Hagenbuch, W. (2020). Won't You Be My Neighbor? Creating an Interconnected Onsite and Online Christian Community [PhD Thesis]. Lancaster Theological Seminary.

Hanberger, A. (2011). The Real Functions of Evaluation and Response Systems. Evaluation, 17(4), 327349. https://doi.org/10.1177/1356389011421697.

Idris, M. (2017). Children Education in the Islamic Family A Study of Tuhfah Al Maudud bi Ahkam Al Maulud by Ibn Qayyim Al Jauziyyah (W.751/1350). IJLRES-International Journal on Language, Research and Education Studies, 1(1), 67-79.

Lipsitch, M., Swerdlow, D. L., \& Finelli, L. (2020). Defining the epidemiology of Covid-19-Studies needed. New England Journal of Medicine, 382(13), 1194-1196.

M. Barnett, T., Thorne, N., Coles, D. C., \& Swindle, T. (2019). The Role of Family: Understanding the Childhood and Current Family Environment of Early Care and Education Teachers. Journal of Education and Human Development, 8(4), 8-17. https://doi.org/10.15640/jehd.v8n4a2.

Maunah, B. (2019). The Contribution of Family and Community Education in Realizing the Goals of School Education. American Journal of Education and Learning, 4(2), 292-301. https://doi.org/10.20448/804.4.2.292.301.

Monitor, I. L. O. (2020). COVID-19 and the world of work: Impact and policy responses. International Labour Organization, March, 1-15.

Murphy, M. P. A. (2020). COVID-19 and Emergency eLearning: Consequences of the Securitization of Higher Education for Post-Pandemic Pedagogy. Contemporary Security Policy, 0(0), 1-14. https://doi.org/10.1080/13523260.2020.1761749.

Ramelli, S., \& Wagner, A. F. (2020). Feverish stock price reactions to covid-19..

Roostin, E. (2018). Family Influence on the Development of Children. Journal of Elementary Education, 2(1), 1-12. https://doi.org/10.1017/CB09781107415324.004.

Suciati. (2016). Islamic Education of Children With Parents as Indonesian Migrant Workers (Case Study in Karangwotan Village, Pati, Central Java). QIJIS: Qudus International Journal of Islamic Studies, $4(2), 138-151$.

Suh, H. (2011). Collaborative Learning Models and Support Technologies in the Future Classroom. International Journal for Educational Media and Technology, 5(1), 50-61.

Tiliouine, H. (2014). Islamic Education and Youth Well-Being in Muslim Countries, With a Specific Refernce to Algeria. In A. Ben-Arieh, F. Casas, I. Frønes, \& J. E. Korbin (Eds.), Spring (Issue January 2014). Springer US. https://doi.org/10.1007/978-90-481-9063-8. 
Viner, R. M., Russell, S. J., Croker, H., Packer, J., Ward, J., Stansfield, C., Mytton, O., Bonell, C., \& Booy, R. (2020). School Closure and Management Practices During Coronavirus Outbreaks Including COVID-19: A rapid Systematic Review. The Lancet Child and Adolescent Health, 4(5), 397-404. https://doi.org/10.1016/S2352-4642(20)30095-X. 